\title{
HARMONIZATION OF PROTECTION PRINCIPLES OF MIGRAN WORKERS' RIGHT TO HEALTH IN THE EFFORT OF ASEAN UNIVERSAL HEALTH COVERAGE IMPLEMENTATION
}

\author{
Muhammad Asphian Arwin and Aktieva Tri Tjitrawati \\ Fakultas Hukum Universitas Airlangga, Surabaya - Indonesia \\ E-mail: muh.asphianarwin@yahoo.co.id
}

\begin{abstract}
Millions of workers migrate within ASEAN countries each year. Malaysia, Singapore, Thailand and Brunei Darussalam as recipient countries while Indonesia, Philippines, Thailand, Cambodia, Laos and Vietnam as senders of migrant workers. Migrants, who work in both formal and informal sectors, play important roles to increase national income for both sender and recipient countries, unfortunately, they lack of welfare distribution including health insurance by both countries. This research is aimed to find an alternative solution to the problem by proposing the concept of UHC implementation in ASEAN. In the context of ASEAN law, all ASEAN people could enjoy rights of health insurance from ASEAN countries. This research is a normative research, using conceptual and statute approach. The result of the analysis is expected to generate concepts which can be underlying the arrangement of public health insurance in ASEAN countries, subsequently, to be used as material for drafting the ASEAN UHC.
\end{abstract}

Keywords: protection principle, migrant workers, health care

\begin{abstract}
Abstrak
Jutaan buruh saling bermigrasi dari dan ke negara-negara ASEAN setiap tahunnya. Malaysia, Singapura, Thailand dan Brunai Darusalam sebagai penerima, sementara Indonesia, Philipina, Thaliand, Kamboja, Laos dan Vietnam sebagai negara pengirim. Buruh migran yang bekerja di sektor formal maupun informal dapat meningkatkan pendapatan nasional negara pengirim maupun penerima, namun disisi lain, mereka kurang mendapatkan distribusi kesejahteraan termasuk perlindungan kesehatan, baik oleh negara pengirim maupun negara penerima. Penelitian ini ditujukan untuk mencari alternatif penyelesaian masalah melalui pemberlakuan UHC di ASEAN. Dalam kerangka hukum ASEAN terdapat kehendak agar seluruh masyarakat ASEAN dapat menikmati hak atas kesehatan dari Negara-negara ASEAN. Penelitian ini merupakan penelitian normatif, dengan menggunakan conceptual dan statute approach. Hasil analisis diharapkan menghasilkan konsepkonsep yang melandasi pengaturan jaminan kesehatan masyarakat di negara-negara ASEAN, untuk selanjutnya bisa digunakan sebagai bahan untuk penyusunan rancangan UHC di ASEAN
\end{abstract}

Kata kunci : prinsip perlindungan, buruh migran, health care

Introduction

In the contexts of the protection of migrant workers' rights in ASEAN, ASEAN countries can be categorized in two groups; Sender countries which are Indonesia, Philippines, Vietnam, Laos, Cambodia, and Myanmar; and recipient countries which are Malaysia, Singapore, Brunei Darussalam and Thailand. This grouping is based on how large the signing of migrant workers to the related countries. This is influenced by job availability in ASEAN countries to gain income, protection also proper life. The indicator is measured by the scale of Intra-ASEAN migrant workers that can be seen on the following table.

Study which is conducted by the international transparency shows that there are still many violations of migrant workers' rights by recipient state including rights of health. ${ }^{1}$ The study by Norma Awang Noh clarified that dis-

Amnesty International, 2010, Trapped the Exploitation of Migrant Workers In Malaysia, Amnesty International Publishing; 
crimination over migrant workers still persists. Even though they have documents, it occurs when they use health insurance at hospitals in Malaysia; and Devadason finds out that migrant workers who have no documents at all do not have any access to health service due to the law system and health services because related countries do not allow it. ${ }^{2}$

Table Inventory of Intra-ASEAN Migrant

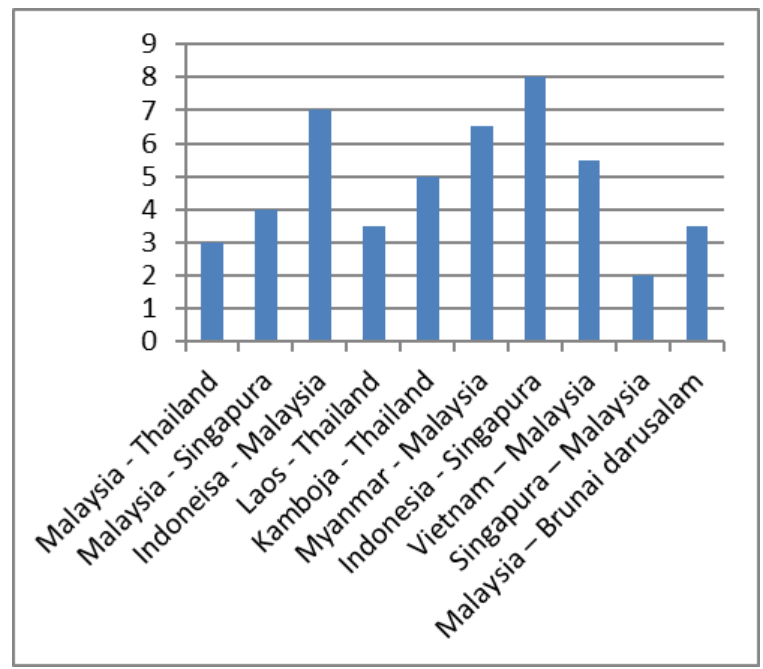

Source : UN 2015-2016 UN (United Nations) Trends in International Migrant Stock

Those studies confirm that the rights over the access of health for migrant workers have not yet been given by receiving state. In fact, Universal Declaration of Human Rights (UDHR) states that every country is in accountability of doing efforts to increase society's health degree to the highest based on the principle non-discriminative, participative, and sustainable. ${ }^{3}$ This norms bind all ASEAN countries, including the ones which did not ratify it, considering UDHR contains pre-emptive norms that binds all countries in the world (jus cogens). The obligation in UDHR is elaborated in the ASEAN Economy Community (AEC) Blueprint program 2025 that attach protection program health care for countries in ASEAN area for the

2 Evelyn S. Devadason and Chan Wai Meng, "Policies and Laws Regulating Migrant Workers in Malaysia: A Critical Appraisal, Journal of Contemporary Asia, Vol. 44 No. 1 January, 2014, p. 25.

3 Riri Anggraeni, "Perlindungan Hukum Bagi Irreguler Migrant Workers Indonesia Di Kawasan ASIA Tenggara (Dalam Perspektif Hukum HAM Internasional), Jurnal Yuridika, Vol. 32 No.2, May, 2017, p. 312. whole society in ASEAN are able to enjoy Universal Health Coverage that consists of: ${ }^{4}$ first, the necessary service access with a good quality that is composed of prevention, enhancement, medical treatment, rehabilitation, and care; secondly, financial protection by paying attention to financial difficulty or the incapability to pay the service in need; thirdly, justice for all people in a whole.

The motivation to implement UHC principle is still nationwide for it is just to protect the health of citizen of one country, excluding migrant workers in receiving state. ${ }^{5}$ The implementation of UHC in a national way does not come with a possibility for the migrant workers to gain rights of health access, considering that this rights giving by sending state is limited by jurisdiction limit in its country's territory. Meanwhile, receiving state usually make a special treatment for the foreigner from their national prosperity distribution system. The implementation of UHC in ASEAN level is expected to give protection of right to health for migrant workers from one ASEAN country who works in other ASEAN countries. ${ }^{6}$

\section{Discussion}

Right to Health Protection in Framework of ASEAN Economy Community 2025

One of the pillars above which contain provisions on Health care in Blue Print 2025 is ASEAN Economy Community. Generally in Health care program 2025: ASEAN will continue to promote the development of a strong health care industry that will contribute to better health care facilities, products and services to meet the growing demand for affordable and quality health care in the region. The development of the health care industry in the region

4 Vivian Lin, Director, "Health Sector Development WHO (Western Pasific Regional Office)," Available on website http: //www. healthfirst.org.au, 2015.

5 Wan Yun Low, Wen Ting Tong, Hons and Collin Binns, "Migrant Workersin Asia Pasific and Their Rights to Health", Asia-Pasific Journal of Public Health, Vol. 27 No. 6, July, 2015, p. 585.

6 Saleema Ravzi, Amir Ulla Khan, "Health Financing in South Asia-The Role of Public-Private Partnerships", Sage Journal South Asian Survey, Vol. 22 No. 1, March, 2015. p.23. 
will include traditional knowledge and medicine, taking into account the importance of effective protection of genetic resources, traditional knowledge, and traditional cultural expressions.

The program above is the first step in the development of a better health facilities to provide affordable and high quality health facilities in ASEAN. ${ }^{7}$ Strategic measures are designed to develop the program, those are: first, continue opening up of private health care market and Public-Private Partnership (PPP) investments in provision of universal health care in the region; second, further harmonization of standards and conformity in health care products and services, such as common technical documents required for registration processes and nutrition labeling; third, promote sectors with high-growth potential such as health tourism and e-health care services, which will not have negative impact on the health care system of each ASEAN Member State; fourth, promote strong health insurance systems in the region; fifth, further facilitate the mobility of health care professionals in the region; sixth, enhance further development of ASEAN regulatory framework on traditional medicines and health supplements, through the setting of appropriate guidelines or frameworks; and seventh, continue developing and issuing new health care product directives to further facilitate trade in health care products in the region.

To embody the health care program above, it requires a Division under the auspices of ASEAN social-cultural community in the framework to embody Universal Health Coverage thoroughly for ASEAN people especially for migrant workers. That Division is part of the subsystems on Committee of the Regions and Economic and Social Committee (EESC) with added the task and function as System Control of health care Region in ASEAN that will control the implementation of overall health facilities

Ling Zhu, Jennifer H. Clarack, "Rights without Access: The Political Context of Inequality in Health Care Coverage in the U.S. States", Sage Journals State Politics and Policy Quarterly, Vol. 15 No. 2, June, 2015, p. 239262 in every ASEAN countries. ${ }^{8}$ Besides, the division playing a role to give suggestions towards ASEAN countries such as making ASEAN Health Insurance Card (AHIC) similarly with European Union to give guarantee thoroughly for European people in ASEAN countries.

The use of AHIC can be a materialization of countries responsibility for their community in other country because it is bounded by the nation system that is national social guarantee such as health service, the costs, the risk and how to pay medical expenses. Those must be included in International agreement by ASEAN countries. Therefore, to constitute a division under EESC, it must have the same principle with UHC, those are Accessibility, Quality and Affordability to be implemented to every ASEAN country.

Both European Union (EU) and ASEAN have the committee to manage migrant workers. ${ }^{9}$ Yet, concerning to the health service for the society and the workers, EU has announced European Health Insurance Card to guarantee the public service access for those who belong to EU's member society to get medical treatment from doctor, pharmacy, hospital or health center. It can be used by all EU's countries people including the legal migrant workers who work in the EU's member countries.

Unfortunately, the European Health Insurance Card does not claim certain things: first, European Health Insurance Card is not an alternative to travel insurance. It does not cover any private health care or costs such as a return flight to your home country or lost/stolen property. Second, European Health Insurance Card does not cover your costs if you are travelling for the express purpose of obtaining medical treatment; and third, European Health Insurance Card does not guarantee free services. As each country's health care system is diffe-

8 System Control of health care Region in ASEAN is a term the author proposes to Sub division of Committee of the Regions and Economic and Social Committee (EESC) which functions as supervisory agent of health care implementation in ASEAN wide.

9 Jaime Calderon, Barbara Rijks, and Dovelyn Rannveig Agunias, "Asian Labour Migrants and Health : Exploring Policy Reutes," Migration Policy Institute, Issue No.2, June, 2012. 
rent services that cost nothing at home might not be free in another country.

The uncovered costs are travelling insurances that does not include private health care. ${ }^{10}$ This protection model is expected to be an input to the protection model in ASEAN regions, especially for the receiving state and the sending state of the migrant workers. Therefore, the EU's protection model can provide better protection in health care access for the society and migrant workers in ASEAN regions. The ASEAN's countries commitment in protecting migrant workers' right to health is still low. There is still disparity acts done by the country to the migrant workers with document. It is because there is no agreement about legal instrument of the migrant wokers' right development and protection between these countries, particularly in health matter.

UHC aims to ensure all people can access the health treatment they need without any financial trouble in paying the cost and to ensure them get their right of health such as health and medicines and technology access, and health expert capacity. Hence, it requires harmonization of UHC concepts and the same service standardization in serving the society especially the migrant workers. ${ }^{11}$ This standardization is implemented in the basic health service facilities, medical treatment, and the funding.

\section{Harmonization of Corresponding Principles as the Foundation for Implementation of UHC in the ASEAN Scope}

Harmonization can only be done if there is similarity or harmony of principles and legal concepts as the basis of harmonization. From studies conducted on the implementation of health insurance in ASEAN countries, it appears that almost all countries have or are very will-

10 Aaron Reeves, Martin Mckee, and David Stuckher, "The Attack on universal Health Coverage in Europe: recesion, austerity and unmet needs", European Jurnal of Public Health Vol. 25 No. 3, June 2015, p. 364.

11 Jennifer Reddock, "Seeking consensus on Universal Health Coverage indicators in sustainable development goals", Journal of Health Services Research \& Policy, Vol. 22 No.3, May 2017, p. 179. ing to apply UHC principles for the distribution of the health rights in their country. The nonimplementation of the UHC principle in the health insurance system by an ASEAN country is more due to the inability of the State in carrying out its system, the lack of an integrated health management system, the limited number of health facilities to provide health services, and the lack of administrative means to manage health insurance and lack of funding to provide health services. Countries such as Myanmar, Laos and Cambodia in providing universal health insurance (UHC) experience obstacles, such as: first, low government budget in health sector; secondly, the inequality between the number of doctors - patients in different areas of the country; and third, the potential threat of contiguous and non-contiguous diseases to poor communities in ASEAN countries due to low nutritional intake and poor sanitation and the environment in which they live. ${ }^{12}$ Thus, harmonization of regulation and standardization of health services as the basis for formulating the framework of implementing the principles of UHC in ASEAN should be placed within the framework of understanding the different levels of ability among these ASEAN countries.

In terms of migration population in ASE$\mathrm{AN}$, it is seen that most migrants are migrant workers of some ASEAN countries (Indonesia, Philippines, Vietnam, Cambodia, Myanmar and Laos) as sending countries and Malaysia, Singapore, Brunei Darussalam, and Thailand as receiving countries. Therefore, the implementation of the UHC principle will be more efficient if the scope is firstly restricted to the provision of health services towards the migrant workers in the State where the laborers work.

The enactment of ASEAN single market will enlarge the number of migrant workers among ASEAN countries. ASEAN single market will also increase the number of health service implementation among ASEAN countries. ${ }^{13}$ This

12 Indranil Mukhopadhyay, "Universal Health Coverage: The new Face of Neoliberalism", Social change Sage Journals, Vol. 43 No. 2, July 2013, p. 175-177.

13 Thomas K Thomas, "Role of Health insurance in enabling universal health coverage in India: A critical re- 
will facilitate the implementation of ASEAN UHC because the sending country can involve private health services which is established in the receiving country to give their citizens facilities abroad.

Basically, almost all ASEAN countries are implementing health care system with UHC principle, it is just implementation of UHC principle in each country is different. These differences are largely determined by the level of community welfare, the national income of the State and the welfare distribution system by the State. Thus, the selection of the principles used as the basis for the arrangement must be adapted to these objective conditions. From the examining results on the application of UHC principles in ASEAN countries and harmonized with the principles of protection of the right to health set forth in ASEAN law, it can be identified some of the corresponding principles of UHC's understanding in ASEAN, those are: first, the Principle of Health as Human Rights (HAM). International law affirms the state's obligation to fulfill those rights in Article 22 of the Universal Declaration of Human Rights (UDHR) by stating:

Everyone, as a member of society, has the right to social security and is entitled to realization, through national effort and international co-operation and in accordance with the organization and resources of each State, of the economic, social and cultural rights indispensable for his dignity and the free development of his personality." 18 This obligation is confirmed by Article 25 of UDHR: "Everyone has the right to a standard of living adequate for the health and well-being of himself and of his family, (...) medical care and necessary social services, and the right to security in the event of unemployment, sickness, disability, widowhood, old age or other lack of livelihood in circumstances beyond his control."

Almost all ASEAN country ratify UDHR, and even they do not, this principle is valid for countries as a peremptory norm (jus cogens) that tied

view", Journal Health Services Management Research, Vol. 29 No. 4, November 2016, p. 102. the countries as a basic value in international law.

Second, principle justice, equality and proportion. Justice principle and equality is a principle that is very difficult to do in terms of giving access and health services. In international level, equality problem usually related to the gap of countries access on health resources. The developed countries usually have a strength and greater skillfulness of health access. While poor countries usually have greater obstacles to get an access to health resources, especially when they meet with financial ability to buy and provide medicinal treatment. A variation in welfare level between ASEAN countries will become the main problem in applying this principle. ${ }^{14}$ The qualification of ASEAN countries into sending and receiving countries also complicate to apply this principle. Thus, equality must stay in that proportion, where ASEAN developed countries do not stay in a position as "dairy cows" in a system of health implementation in ASEAN, and on the other side does not threat ASEAN undeveloped countries as "a spoiled child" that can easily get every facility. In national level, equality principle usually related to disparities inaccessibility of health for a group of society distinguished by level of prosperity, gender, ethnic group, the region of residence, etc. Before organizing UHC system on a regional basis, the member of ASEAN countries must have the same perception first, considering there is a prosperity disparity among them.

Third, access principle to health services as a part of human rights protection. Rights otohealth do not always same with rights on health services. ${ }^{15}$ The implementation of rights of health services is more difficult because it relates to technical problems for giving health services influenced by health services charac-

14 Bambang Burwoko, H. "Sistem Jaminan Sosial di Malaysia: Suatu Tata Kelola Penyelenggaraan per program yang berbasis pada pelembagaan yang terpisah", $E$ Jurnal Widya Ekonomika, Vol. 1 No. 1, November 2014, p.35.

15 Felix F. Widjaja," Universal Health Coverage In Indonesia - the forgotten prevention," Medical Journla of Indonesia, Vol. 23, No. 3, Edisi August, 2014, p.125-126 
teristics including social aspect in one side and commercial aspect in the other side. In social aspect, society was given an easy way to reach health services, satisfying facilities service, an access to a health services place. ${ }^{16}$ It aims to make people easier to access the health services. ${ }^{17}$ However, a government must take an appropriate policy to give maximum health services with a lower cost for society, so this case in future will give additional services for society and its easier access. Giving a rights of health service depends on health service system in a country that related and usually determined by a distribution of welfare system. ${ }^{18}$ Socialistic countries usually put the health service as a part of a distribution of social welfare controlled by a state which results in a cheap even free payment. This case also applied to some liberal economic countries that practice the theory of welfare state. Despite self-claiming as a welfare state, United State does not give a free health service for their society, the health service is given through the mechanism insurance that must be paid by themselves.

Almost all ASEAN Member have implemented the UHC principle. Unfortunately, to make the principle is well-implemented and hold as the guidance for all the members is not easy to be done especially, in health service aspect. The very different economic level among ASEAN members, especially sending and receiving states, will be hard to determine the health service standard must be given to the migrant workers. ${ }^{19}$ The richer state will demand a higher fee for the given health service

16 Fabrizio Tediosi, Aureliano Finch, Christina Procacci, Robert Marten, Eduardo Missoni," BRICS countries and the global movement for universal healthcoverage, The Journal on health policy and systems research Vol. 31, No.6, July, 2016, P. 717-728

17 Devi Sridhar, Martin McKee, Gorik Ooms, Claudia Beiersmann, Eric Friedman, Hebe Gouda, Peter Hill, Albrecht Jahn, "Universal Health Coverage and the Right to Health From Legal Principle to Post-2015 Indicators", International Journal of Health Services, Vol.45 No.3 June, 2015, p.496-497

18 Aktieva Tri Tjitrawati, "Perlindungan Hak dan Pemenuhan Akses Atas Kesehatan Bagi Tenaga Kerja Indonesia di Malaysia, Jurnal Mimbar Hukum, Vol. 29 No.1, Edisi February, 2017, p. 61

19 Koesrianti, "Kewajiban Negara Pengirim dan Negara Penerima atas perlindungan pekerja Migran, Jurnal Diplomasi, Vol. 2 No 1, March,2010, p. 28 while the poor may find a difficult condition in paying the service. The implementation of proportional principle must be able to determine the obligation and rights for all the party.

Fourth, nondiscriminatory principle. The study done by Norwa Awang and others showed that the discrimination of health service given by the hospital to the documented migrant workers in Malaysia still exists. Furthermore, if the documented migrant affected by the discrimination, the undocumented are even not given the health access at all. Consequently, the reverence for the humanity and towards the base values of medical must be well held to wipe out the discrimination to the patient.

Fifth, collaboration and teamwork principle. UHC principle is impossible to be implemented in ASEAN regional level unless there is a good teamwork and collaboration between ASEAN members especially the health service institutions. Team work is a must to create the implementation of UHC and determine the obligations and rights between the teams. Then, collaboration is also needed among the health service providers and the UHC finance officer.

Sixth, accessibility and availability principle. The implementation of UHC principle in ASEAN level requires insurance from the members about the accessibility of the health facility for all other members of ASEAN. Moreover, the states also must secure the availability of the sufficient health service facilities for the migrant workers. Considering that health aspect also relates to the economic matter where the service always linked to the economic unit price. Hence, the fee that must be paid by the sending states or the migrant workers must be well arranged for the accessible health service in the receiving state.

Seventh, accountability principle. In implementing the health service at any level, the accountability principle must be secured. This principle is very important in implementing health service for its close relation to human life. The well determined standards of health service in implementing the UHC for ASEAN will help improve the accountability of health service among the states. 
Eighth, quality principle. The quality of the given health service must be assured in the implementation of UHC in ASEAN, given that the health service is not only about the quantity but also the quality. The good determination of health service quality standard that become the definite migrant workers' rights must be done in order to bring the UHC principle into ASEAN level.

Ninth, universality principle. The principle of medical ethics is applied universally, consequently, the implementation of UHC in health service realization must be based on seven principles of the universality including nonmaleficience, beneficience, autonomy, health maximation, efficiency, justice, and proportionality. ${ }^{20}$

Those principles should be used as the basis in determining the norms that will be used as basic cooperation arrangement of UHC implementation in ASEAN level. The implementation of this cooperation will be difficult considering the existence of objective condition in ASEAN countries which are very different and variable from every aspect such as economy, politics, social and culture. However, the UHC implementation almost in every ASEAN countries becomes the strong basis in implementing UHC in ASEAN level.

If determining the norms based on international agreements on UHC implementation of UHC has been done, the next step is to determine the health insurance and health service standardization. To do so, it needs to be reinforced what health insurance and health service that are covered by the administrator. ${ }^{21} \mathrm{It}$ also needs to be reinforced how the UHC procurement cost covered by ASEAN countries, and whether this is only implemented by ASEAN countries government or also involves private party. Through this standardization, it is expec-

20 Howard L Sobel, Dale Huntington, Marleen Temmerman, "Quality at the centre of universal health coverage", The Journal on health policy and systems research, Vol. 31 No. 4, May 2016, p. 547-549.

21 Rami Yassoub, Mohamad Alameddine, Shadi Saleh, Shadi Saleh, "The Path Toward Universal Health Coverage Stakeholder Acceptability of a Primary Care Health Benefits Package in Lebanon", International Journal of Health Services, Vol. 47 No. 2, April 2017, p. 356. ted to avoid discrimination for migrant workers.

The principle above accommodates country's obligation in implementing UHC principles in its country, as in Indonesia that supports the sustainability of National Health Insurance. One of the examples is by integrating local health insurance program (Jamkesda) to JKN - KIS (Indonesian Health (ard). ${ }^{22}$ The integration is a synergy the implementation of health insurance for people that are listed by local government using JKN - KIS scheme that is managed by health care and Social Security Management Agency (BPJS). ${ }^{23}$ Moreover, government's support involves scattered Regional Budget (APBD), either membership or infrastructure development related to principle of cooperation and collaboration among institutions that handle health service.

As an effort to optimize the UHC implementation in all ASEAN countries, the member's obligation to pay insurance premium to service providers is the requirement to get health service facility. Thus, principle of nondiscrimination ratified by ASEAN countries can provide protection for migrant workers in every aspect to get the appropriate health service.

\section{Conclusion}

The UHC implementation in almost all ASEAN countries becomes the important base of its implementation within ASEAN. Then, the harmonization principle of law corresponding to the international agreements in UHC implementation is done. The UHC Implementation also requires standard of health services that can be balanced with interests of ASEAN countries due to the existence of a significant welfare disparity between the sending and recipient country of migrant workers.

22 Misnaniarti, "The Context of Policy Implementation Jamkesda In Framework National Universal Health Coverage", Jurnal IImu Kesehatan Masyarakat, Vol. 04 No. 3, November edition, 2013, p.190.

23 Elizabeth Pisani Maarten Olivier Kok Kharisma Nugroho, "Indonesia's road to universal health coverage: a political journey", The Journal on health policy and systems research, Vol. 32 No. 2, March 2017, p.267-276. 


\section{Recommendation}

Members of ASEAN countries need to reinforce the existence of ASEAN Health Insurance card that functions as security of health insurance access for people especially migrant workers. It also needs to be made a custom framework either in form of technical guidance or legal instruments in deployment model by a country, in providing health finance for migrant workers.

\section{References}

Amnesty International. 2010. Trapped the Exploitation of Migrant Workers In Malaysia. Amnesty International Publishing;

Anggraeni, Riri, “Perlindungan Hukum bagi Irreguler Migrant Workers Indonesia di Kawasan ASIA Tenggara (Dalam Perspektif Hukum HAM Internasional). Jurnal Yuridika. Vol. 32 No. 2. May 2017. Pp.310-335. DOI: 10.20473/ydk.v32i2.4773;

Arunanondchai, J,. \& Fink. 2007. Trade In Health Services in the ASEAN Region. Health Promotion International;

Burwoko, H. Bambang. "Sistem Jaminan Sosial di Malaysia: Suatu Tata Kelola Penyelenggaraan Per Program yang Berbasis pada Pelembagaan yang Terpisah". E-Jurnal Widya Ekonomika. Vol. 1 No. 1. November 2014. Pp. 31-42;

Calderon, Jaime; Barbara Rijks, and Dovelyn Rannveig Agunias. "Asian Labour Migrants and Health : Exploring Policy Reutes," Migration Policy Institute, Issue No. 2, Juni, 2012;

Devadason, Evelyn S. and Wai Meng Chan "Policies and Laws Regulating Migrant Workers in Malaysia: A Critical Appraisal. Journal of Contemporary Asia. Vol. 44 No. 1. January 2014. Pp.19-35. DOI: 10.1080/00472336.2013.826420;

Elizabeth, Pisani; Maarten Olivier Kok Kharisma Nugroho. "Indonesia's road to universal health coverage: a political journey". The Journal on health policy and systems research. Vol. 32 No. 2. March.2017. Pp. 267-276. DOI: 10.1093/heapol/czw120;

Farbenblm, Bassina and Elanor Taylor-Nichloson, Sarah Paoleti. 2007. Migran Workers Access To Justice Series. NewYork: Open Society Foundation;
Koesrianti, "Kewajiban Negara Pengirim dan Negara Penerima atas Perlindungan Pekerja Migran”. Jurnal Diplomasi, Vol. 2 No 1, March 2010. Pp.20-42;

Lin, Vivian. Director, "Health Sector Development WHO (Western Pasific Regional Office)," Available on website http://www. healthfirst.org.au, 2015;

Low, Wan Yun; Wen Ting Tong, Hons and Collin Binns. "Migrant Workersin Asia Pasific and Their Rights to Health". Asia-Pasific Journal of Public Health. Vol. 27 No. 6. July 2015. Pp.584-587. DOI: 10.1177/ 1010539515600007;

Misnaniarti. "The Context of Policy Implementation Jamkesda In Framework National Universal Health Coverage". Jurnal Ilmu Kesehatan Masyarakat. Vol. 04 No.3. November 2013. Pp.188-196;

Mukhopadhyay, Indranil. "Universal Health Coverage: The new Face of Neoliberalism". Social change Sage Journals. Vol. 43 No. 2. July 2013. Pp.177-190. DOI: 10.1177/ 0049085713492281 ;

Murti, Bhisma. 2011. Kesetaraan Kesehatan Berpola Jaminan Pemeliharaan Kesehatan Masyarakat di era Desentralisasi menuju Cakupan Semeste, Universitas Sebelas Maret: Instittut of Health Economy and Policy Studies (IHEPS);

Rami, Yassoub; Rami Alameddine, Mohamad and Saleh, Shadi, "The Path Toward Universal Health Coverage Stakeholder Acceptability of a Primary Care Health Benefits Package in Lebanon, International Journal of Health Services Vol.47 No.2, April, 2017, Pp.352-373. DOI. 10.1177/ 0020731415585990

Ravzi, Saleema and Amir Ulla Khan. "Health Financing in South Asia-The Role of PublicPrivate Partnerships". Sage Journal South AsianSurvey. Vol. 22 No. 1. March 2015. Pp. 15-36. DOI: 10.1177/0971523117695143;

Reddock, Jennifer. "Seeking consensus on Universal Health Coverage indicators in sustainable development goals". Journal of Health Services Research \& Policy. Vol. 22 No. 3. May 2017. Pp.178-182. DOI: 10.1177/1355819617704676

Reeves, Aaron; Martin Mckee and David Stuckher. "The Attack on universal Health Coverage in Europe : recesion. austerity and unmet needs". European Jurnal of Public 
Health. Vol. 25 No. 3. June. 2015. Pp. 364-365. DOI: 10.1093/eurpub/ckv040;

Sobel, Howard L; Dale Huntington, Marleen Temmerman. "Quality at the centre of universal health coverage". The Journal on health policy and systems research. Vol. 31 No.4. May 2016. Pp.547549. DOI: 10.1093/heapol/czv095;

Sridhar, Devi; Martin McKee, Gorik Ooms, Claudia Beiersmann, Eric Friedman, Hebe Gouda, Peter Hill, Albrecht Jahn. "Universal Health Coverage and the Right to Health From Legal Principle to Post-2015 Indicators. International Journal of Health Services. Vol 45 No. 3 June 2015. Pp. 496-506. DOI: 10.1177/0020731415584554;

Tediosi, Fabrizio; Aureliano Finch, Christina Procacci, Robert Marten, Eduardo Missoni. "BRICS countries and the global movement for universal healthcoverage". The Journal on health policy and systems research. Vol. 31. No. 6. July 2016. Pp. 717-728. DOI: 10.1093/heapol/czv122

The ASEAN Secretariat Public Outrech and Civil Society Division, November 2015. ASEAN Economic Community Blueprint 2025. Jakarta: The ASEAN Secretariat Public Outrech and Civil Society Division;

Thomas, K. "Role of Health insurance in enabling universal health coverage in India: A critical review". Journal Health Services Management Research. Vol.29 No.4. November. 2016. Pp.99-106. DOI: 10. 1177/0951484816670191;

Tjitrawati, Aktieva Tri. "Perlindungan Hak dan Pemenuhan Akses Atas Kesehatan Bagi Tenaga Kerja Indonesia di Malaysia". Jurnal Berkala Mimbar Hukum. Vol. 29 No.1. February 2017. Pp.55-66. DOI: 10.22146/ jmh.17651;

Widjaja, Felix. "Universal Health Coverage In Indonesia - The Forgotten Prevention". Medical Journla of Indonesia. Vol. 23 No. 3. August 2014. Pp.125-126. DOI: 10. $13181 / \mathrm{mji} . \mathrm{v} 23 \mathrm{i} 3.1070$

World Health Organization. 2005. World Health Organization, Department of Health Systems Financing, Health Financing Policy. Achieving universal health coverage: Developing the health financing system, Number 1. Technical brief for policymakers;
Zhu, Ling and Jennifer H. Clarack. "Rights without Access: The Political Context of Inequality in Health Care Coverage in the U.S. States", Sage Journals State Politics and Policy Quartely, Vol. 15 No. 2, June 2015. Pp.239-262, DOI: 10.1177/1532440014568569. 